\title{
TRANSEPIDERMAL WATER LOSS VALUE COMPARISON BETWEEN TENGKAWANG AND DURIAN SEED OIL LOTION
}

\section{PERBANDINGAN NILAI TRANSEPIDERMAL WATER LOSS DARI SEDIAAN LOSION MINYAK TENGKAWANG DAN MINYAK BIJI DURIAN}

\author{
Irma Ramadhani Febriaty*, Thamrin Usman, Andi Hairil Alimuddin \\ Progam Studi Pascasarjana Kimia, Fakultas MIPA, UniversitasTanjungpura, \\ Jl. Prof. Dr. H. Hadari Nawawi, Pontianak 78124 \\ *email: irmaramadhanifebriaty@gmail.com
}

\begin{abstract}
Body epidermis has an important health function to prevent body dehydration. This research aims to compare Transepidermal Water Loss (TEWL) values between durian seed oil and tengkawang oil. Skin that had been applied with tengkawang oil and durian seed oil lotion were tested for irritation and TEWL values. The tengkawang oil had an acid number of $17 \mathrm{~g} / \mathrm{mol}$ and contained $8.54 \%$ free fatty acid, while the durian seed oil had an acid number of $6.34 \mathrm{~g} / \mathrm{mol}$ and contained $2.89 \%$ free fatty acid. Irritation testing was done using lotion containing $100 \%$ of each oil. TEWL analysis on skin applied with the tengkawang oil lotion after 1 hour showed that the lotion could reduce epidermal water evaporation by $35.23 \%$ compared to the skin condition before treatment. Epidermal water evaporation reduction at the second, third and fourth hours after the tengkawang oil lotion application was $31.33 \%, 33.93 \%$ and $27.9 \%$, respectively. TEWL analysis on skin applied with the durian seed oil lotion after 1 hour showed that the lotion could reduce epidermal water evaporation by $11.34 \%$ compared to the skin condition before treatment. Epidermal water evaporation was reduced $14.64 \%, 10.53 \%$ and $2.99 \%$ at the second, third and fourth hours after application of the durian seed oil. Based on these results, it can be concluded that tengkawang oil gives better TEWL values compared to durian seed oil.
\end{abstract}

Keywords: Durian's seed oil, tengkawang oil, Transepidermal Water Loss

\begin{abstract}
ABSTRAK
Kulit merupakan bagian tubuh manusia yang berperan penting, untuk segi kesehatan dimana salah satu fungsinya adalah mencegah terjadinya kehilangan cairan tubuh pada manusia Penelitian ini bertujuan untuk menentukan perbandingan nilai TEWL antara minyak biji durian dan minyak tengkawang. Telah dilakukan perbandingan uji iritasi dan pengukuran Transepidermal Water Loss (TEWL) kulit yang dioles lotion minyak tengkawang dan minyak biji durian. Minyak tengkawang yang diperoleh memiliki nilai bilangan asam $17,00 \mathrm{~g} / \mathrm{mol}$ dan kadar asam lemak bebas 8,54 \%, sedangkan minyak biji durian diperoleh bilangan asam sebesar $6,34 \mathrm{~g} / \mathrm{mol}$ dan kadar asam lemak bebas $2,89 \%$. Uji iritasi minyak tengkawang dan minyak biji durian dilakukan pada konsentrasi $100 \%$ terhadap kulit. Pengukuran nilai TEWL kulit yang diolesi losion minyak tengkawang pada 1 jam pertama mampu mengurangi penguapan air dari kulit sebesar 35,23\% terhadap kondisi awal. Pada jam kedua, ketiga dan keempat minyak tengkawang mengurangi penguapan air dari kulit sebesar 31,33\%, 33,93\% dan 27,9\%. Pengukuran nilai TEWL kulit yang diolesi losion minyak biji durian pada 1 jam mampu mengurangi penguapan air dari kulit sebesar 11,34 \% terhadap kondisi awal. Pada jam kedua sampai jam keempat secara berturut-turut losion minyak biji durian mampu mengurangi penguapan air dari kulit sebesar 14,64 \%, 10,53\% dan 2,99\% dari kondisi awal.
\end{abstract}


Berdasarkan nilai tersebut dapat disimpulkan bahwa minyak tengkawang meberikan nilai TEWL yang lebih baik daripada minyak biji durian.

Kata Kunci: Losion, minyak biji durian, minyak tengkawang, transepidermal water loss

\section{PENDAHULUAN}

Kulit merupakan bagian tubuh manusia yang berperan penting dalam menjaga kesehatan.-Salah satu fungsinya adalah mencegah terjadinya kehilangan cairan tubuh pada manusia. Kulit manusia terdiri atas tiga lapisan utama yaitu lapisan epidermis, lapisan dermis, dan lapisan hipodermis. Pada lapisan epidermis terdapat stratum korneum yang memberikan kontribusi bagi kelembaban kulit karena stratum korneum terdiri atas 10-30 \% air (Misnadiarly, 2006). Kehadiran air dalam lapisan epidermis adalah penting untuk melindungi kekeringan kulit. Kulit yang kering akan terlihat kasar, pecah-pecah, dan gatal-gatal. Kekeringan pada kulit dipengaruhi oleh beberapa faktor, yaitu faktor usia, sinar matahari, tekanan psikis, konsumsi obat, perubahan cuaca, pola makan dan gaya hidup dimana faktor-faktor tersebut dekat dengan kehidupan kita (Morino, 2001). Salah satu solusi yang dapat dilakukan untuk mengatasi masalah kekeringan kulit adalah dengan menutup permukaan kulit untuk menghambat penguapan air yang dikenal dengan oklusan.

Zat penutup (oklusan) yang baik adalah oklusan yang bersifat hidrofob. Zatzat ini membantu stratum korneum menahan air. Oklusan yang digunakan dalam pelembab kulit mengandung minyak nabati. Minyak pada pelembab kulit membentuk selaput oklusif di atas permukaan kulit dan menghindarkan kadar air turun di bawah batas minimal yaitu $10 \%$ (Misnadiarly, 2006). Minyak yang dibutuhkan sebagai pelembab kulit adalah minyak yang mengandung asam lemak essensial terutama mengandung asam linoleat dan asam oleat. Hal ini dikarenakan asam-asam tersebut merupakan unsur utama penyusun ceramid yang melekat pada stratum korneum. Komposisi asam oleat dalam losion pelembab kulit mencapai $55 \%$ dan asam linoleat 1,5\% (Alander et al., 2006). Sumber asam lemak esensial ini dapat diperoleh dari minyak mineral maupun dari tumbuhan. Namun demikian, asam lemak yang berasal dari tumbuhan lebih baik dibandingkan dengan asam lemak yang berasal dari minyak mineral. Hal ini dikarenakan lebih mudah bercampur dengan lemak kulit dan lebih mampu menembus sel-sel stratum korneum. Tranggono dan Fatma (2007) menyebutkan bahwa suatu bahan dapat dijadikan pelembab dengan syarata bahan mudah bercampur dengan lemak kulit, mampu menembus sel-sel stratum korneum dan tidak menimbulkan iritasi pada kulit.

Pada penelitian ini digunakan sumber bahan alam lokal asal Kalimantan Barat yaitu biji tengkawang dan biji durian sebagai bahan aktif pelembab kulit. Buah tengkawang merupakan bahan baku lemak nabati yang berharga lebih tinggi 
dibanding minyak nabati lain seperti minyak kelapa. Minyak tengkawang mengandung asam oleat dan linoleat sebesar 37,4 dan 0,2\%. Keistimewaan minyak tengkawang adalah sifat titik cairnya yang tinggi, yaitu rata-rata $30{ }^{\circ} \mathrm{C}$, sehingga cocok untuk pembuatan margarine, coklat, sabun, lipstik, obat-obatan, lilin, dan lain-lain (Nesaretnam dan Mohd Ali. 1992). Tanaman durian merupakan famili Bombacaceae memiliki minyak pada bagian biji dengan kandungan asam oleat $38,8 \%$, asam linoleat 5,9\%, dan asam $\alpha$-linoleat $3 \%$ (Brown, 1997).

Kandungan asam oleat dan linoleat yang terdapat dalam minyak biji durian dan minyak tengkawang berpotensi untuk dijadikan sebagai komponen utama penyusun pelembab kulit. Hal ini dapat meningkatkan nilai ekonomis dari kedua bahan tersebut terutama dari minyak biji durian karena saat ini biji durian hanya dianggap sebagai limbah bagi sebagian besar masyarakat. Untuk itu perlu dilakukan penelitian tentang daya melembabkan kulit dari minyak biji durian dan minyak tengkawang. Salah satu parameter yang digunakan untuk menguji kemampuan dari suatu bahan dapat dijadikan sebagai bahan baku pembuatan zat oklusan adalah dengan mengukur nilai Transepidermal Water Loss (TEWL) kulit. Nilai TEWL menggambarkan kemampuan suatu bahan dalam mengurangi penguapan air dari kulit (Kanengeiser, 2003). Pengukuran nilai TEWL kulit dilakukan dengan menggunakan alat tewameter. Nilai TEWL yang dihasilkan akan memberikan informasi mengenai kemampuan minyak tersebut dalam mengurangi penguapan air dari kulit. Pemanfaatan minyak nabati sebagai pelembab kulit untuk mempertahankan nilai Transepidermal Water Loss (TEWL) telah banyak dilakukan. Sana (2010) telah memanfaatkan minyak biji durian sebagai pelembap kulit dengan melakukan uji TEWL pada kulit manusia dan uji iritasi terhadap kelinci. Pemanfaatan minyak tengkawang untuk meminimalisir nilai TEWL dan tingkat iritasi terhadap kulit belum ditemukan acuan literaturnya, namun masyarakat lokal menggunakan minyak biji tengkawang sebagai minyak pelembab kulit. Salah satu faktor yang mempengaruhi terhadap kemampuan minyak biji tengkawang sebagai bahan baku pelembap kulit adalah tingginya titik leleh minyak tengkawang yang berkisar 34-39 ${ }^{\circ} \mathrm{C}$. Menurut Soerianegara dan Lemmens (1997), biji tengkawang atau illipe nut mengandung lemak (green butter) yang dapat diolah menjadi minyak goreng, pengganti coklat, bahan farmasi, kosmetik, sabun dan margarine.

Pada penelitian ini akan dilakukan pembuatan sediaan losion pelembab dengan bahan aktif minyak biji durian dan minyak tengkawang. Setelah dilakukan pembuatan sedian losion pelembab kemudian akan dilakukan pengujian nilai TEWL dari minyak biji durian dan minyak tengkawang. Selain pengukuran nilai TEWL kulit, juga akan dilakukan uji iritasi dari masing-masing minyak untuk mengetahui tingkat iritasi dari minyak tersebut pada kulit. 


\section{Alat dan Bahan}

\section{METODOLOGI PENEITIAN}

Alat-alat yang digunakan dalam penelitian ini adalah seperangkat alat gelas laboratorium, timbangan (Ohaus PAJ 1003), termometer, oven (Memmert UN110), seperangkat alat sokletasi (Labu sokletasi, pemanas listrik, sistem pendingin), alat tewameter (TM300).

Bahan-bahan yang digunakan dalam penelitian ini antara lain akuades, n-heksan p.a, biji durian, minyak tengkawang, kertas saring, natrium hidroksida, karbon aktif, metanol, etanol, aseton, metilen klorida, etil asetat, kloroform, isopropyl myristate, arlacel, cosmowax, glycerine, betaine.

\section{Uji iritasi kulit}

Uji iritasi bertujuan untuk melihat apakah minyak tengkawang dan minyak biji durian dapat menimbulkan iritasi pada kulit. Uji iritasi kulit menggunakan kelinci. Perlakuan dilakukan untuk 3 ekor kelinci dimana setiap satu ekor kelinci terhadap 2 titik uji dan 2 titik kontrol. Rambut kelinci dibersihkan 24 jam sebelum uji dilakukan. Rambut kelinci digunting dan dicukur seluas $6,25 \mathrm{~cm}^{2}(25 \times 25 \mathrm{~mm})$ didaerah punggung kiri dan kanan sebagai tempat aplikasi sampel. Setelah 24 jam sampel dioleskan pada kulit yang telah disiapkan.

Pengamatan dilakukan pada 60 menit, 24 jam, 48 jam, 72 jam setelah pemberian sampel. Pengamatan dilakukan secara visual. Titik pengamatan dibandingkan dengan titik kontrol (titik pada tubuh kelinci, dimana letaknya bersebelahan dengan titik uji dan tidak diolesi minyak biji durian dan minyak tengkawang). Warna merah di kulit pada titik uji dibandingkan dengan titik kontrol. Untuk setiap keadaan kulit diberi nilai sesuai metode skoring dari Draize. Nilai yang diberikan pada 24, 48, 72 jam diakumulasi untuk setiap ekor kelinci. Tingkat iritasi disesuaikan dengan tabel Indeks iritasi dihitung dengan cara menjumlahkan nilai dari setiap kelinci percobaan setelah 24 dan 72 jam pemberian sampel iritan, kemudian dibagi jumlah hewan coba. Penilaian iritasinya sebagai berikut pada tabel tingkat iritasi kulit.

\section{Pembuatan Losion Minyak Tengkawang dan Minyak Biji Durian serta Uji Stabilitas Losion}

Setelah uji iritasi minyak tengkawang dan minyak biji durian $100 \%$ tanpa pengenceran diketahui tidak menimbulkan iritasi, selanjutnya minyak tengkawang dan minyak biji durian dibuat losion pelembab. Losion merupakan sediaan kosmetik golongan emolien (pelembut) yang mengandung banyak air. Bahanbahan yang digunakan pada pembuatan losion pelembab dapat dilihat pada tabel 1 . 
Tabel 1. Formulasi Losion Pelembab

\begin{tabular}{cccc}
\hline Nama bahan & Baselosion $(\mathrm{g})$ & $\begin{array}{c}\text { Losion Minyak Biji } \\
\text { Durian }(\mathrm{g})\end{array}$ & $\begin{array}{c}\text { Losion Minyak } \\
\text { Tengkawang }(\mathrm{g})\end{array}$ \\
\hline Cosmowax & 3,1 & - & - \\
IPM & 31,3 & 31,3 & 31,3 \\
Arlacel & 6,3 & 6,3 & 6,3 \\
Glycerin & 3,8 & 3,8 & 3,8 \\
Betain & 1,3 & 1,3 & 1,3 \\
Minyak Tengkawang & - & - & 3,1 \\
Minyak Biji Durian & - & 3,1 & - \\
Aquadest & 76,3 & 76,3 & 76,3 \\
\hline
\end{tabular}

Losion yang sudah jadi diuji stabilitas losion minyak tengkawang dan minyak biji durian dengan metode cycling test. Pengujian dengan metode cycling test meliputi uji organoleptic, uji homogenitas dan pemeriksaan $\mathrm{pH}$.

\section{Pengukuran Transepidermal Water Loss (TEWL)}

Kemampuan melembabkan kulit dapat diuji dengan mengukur nilai TEWL menggunakan alat tewameter. Pengukuran nilai TEWL dilakukan kepada 15 orang sukarelawan dengan kriteria usia 17-45 tahun, jenis kulit normal, jenis kelamin perempuan dan tidak memiliki penyakit atau kelainan kulit. Uji kelembaban kulit ini dilakukan pada kulit tangan manusia bagian bawah tangan kanan dan tangan kiri. Masing-masing tangan terdapat 2 titik uji dengan jarak antara titik adalah 2 $\mathrm{cm}$. Tahap pertama dilakukan pengukuran nilai TEWL base kulit. Nilai TEWL ini merupakan nilai TEWL awal $\left(\mathrm{t}_{0}\right)$ kulit sebelum diberi perlakuan.

Setelah pengukuran TEWL awal dilakukan, kulit diolesi dengan lotion minyak biji durian, losion minyak tengkawang, base losion dan tanpa perlakuan sebagai kontrol. Berat lotion yang dioleskan sebanyak 0,4 gram pada setiap titik. Pengukuran nilai TEWL dilakukan setiap jam selama 4 jam berturut-turut. Kemampuan minyak biji durian menurunkan TEWL kulit ditentukan dalam perubahan TEWL ( $\triangle$ TEWL) yang dinyatakan dalam \%, sesuai persamaan berikut ini.

$$
\Delta \mathrm{TEWL}=\frac{T E W L k e-n-T E W L \text { awal }}{T E W L \text { awal }}
$$

\section{HASIL DAN PEMBAHASAN}

\section{Hasil uji iritasi minyak tengkawang dan minyak biji durian}

Minyak tengkawang dan minyak biji durian $100 \%$ tidak menimbulkan iritasi kulit. Perhitungan indeks iritasi diperoleh dengan merata-ratakan nilai dari erithema dan udema yang diperoleh dengan pengamatan 24 dan 72 jam setelah pemberian, lalu dijumlahkan. Golongan tingkat iritasi yang dihasilkan termasuk dalam golongan iritasi ringan $(0,5-2)$. 
Tabel 2. Hasil Perhitungan Indeks Iritasi

\begin{tabular}{lcc}
\hline Kelompok uji & Indeks iritasi & Tingkat iritasi \\
\hline Kontrol positif (sls) & 3.75 & Sedang \\
Kontrol negative & 0 & Dapat diabaikan \\
Minyak tengkawang & 0 & Dapat diabaikan \\
Minyak biji durian & 0 & Dapat diabaikan \\
\hline
\end{tabular}

Pengujian iritasi dilakukan dengan menggunakan 5 ekor kelinci sebagai hewan uji. Berdasarkan hasil ini menunjukkan bahwa minyak tengkawang dan minyak biji durian tergolong tidak membahayakan, karena dalam proses pengujian tidak menimbulkan edema dan eritema pada hewan uji. Kulit yang diberi kontrol positif menunjukkan terbentuknya eritema dan edema pada kulit hewan uji. Bahan yang digunakan sebagai kontrol positif adalah sodium lauril sulfat (SLS). Senyawa kimia seperti SLS merusak membran lipid keratinosid, kemudian sebagian menembus membran sel dan merusak lisosom, mitokondria dan komponen inti. Kerusakan membran mengaktifkan beberapa mediator seperti fosfolipase, asam arakidonat (AA) yang dirubah menjadi prostaglandin (PG) dan leukotrien (LT), diasilgliserida (DAG), platelet activating lactor (PAF) dan inositida yang menginduksi terjadinya vasodilatasi serta peningkatan permeabilitas vaskular. Vasodilatasi dan peningkatan permeabilitas vaskuler ini yang kemudian menunjukkan gejala eritema dan udema yang disebut iritasi (Gibbs et al., 2002). Berdasarkan data tersebut maka minyak tengkawang dan minyak biji durian dapat diuji pada manusia karena tidak menimbulkan iritasi meskipun pada pemakaian tanpa penganceran.

\section{Pembuatan Losion Minyak Tengkawang dan Minyak Biji Durian serta Uji Stabilitas Losion}

Lotion yang sudah jadi diuji stabilitas losion minyak tengkawang dan minyak biji durian dengan metode cycling test. Pengujian dengan metode cycling test meliputi uji organoleptic, uji homogenitas dan pemeriksaan $\mathrm{pH}$. Pengujian pemeriksaan organoleptik dilakukan pengamatan secara visual yang meliputi bau, warna, bentuk dan tekstur sediaan losion pelembab tengkawang dan minyak biji durian. Ini dilakukan untuk mengetahui losion yang dibuat sesuai dengan warna dan bau ekstrak yang digunakan ${ }^{[11]}$. Hasil penelitian menunjukkan bahwa ketiga formula losion secara fisik tidak mengalami perubahan bau dan warna sampai hari ke-12. Formula losion hingga hari ke-12 tetap berwarna putih dan berbau khas tengkawang dan biji durian.

Uji homogenitas bertujuan untuk melihat dan mengetahui tercampurnya bahan-bahan sediaan losion (Juwita et al., 2013). Pada evaluasi ini, uji homogenitas losion pelembab dilakukan secara visual dengan mengamati warna losion dan ada 
tidaknya bagian-bagian yang tidak tercampurkan dengan baik. Hasil penelitian menunjukkan bahwa semua sediaan losion memiliki homogenitas yang baik, hal ini ditunjukkan ketika sejumlah losion dioleskan pada sekeping kaca terlihat susunan yang homogen dan tidak terlihat partikel kasar. Syarat sediaan losion yaitu jika dioleskan pada sekeping kaca tidak adanya pemisahan antara komponen penyusun emulsi tersebut (Erungan et al., 2009).

Nilai $\mathrm{pH}$ merupakan salah satu parameter penting dalam produk kosmetik. Nilai $\mathrm{pH}$ adalah derajat keasaman suatu bahan atau pengukuran aktivitas hidrogen dalam lingkungan air. Menurut Iswari dan Latifah (2007), pH produk kosmetik sebaiknya mendekati $\mathrm{pH}$ kulit yaitu 5,5. Produk kosmetik yang memiliki $\mathrm{pH}$ jauh dengan $\mathrm{pH}$ fisiologis kulit sekitar 4,5-5,5 akan lebih mudah mengiritasi kulit. Jika sediaan memiliki $\mathrm{pH}$ yang rendah atau asam dapat mengiritasi kulit dan sebaliknya jika $\mathrm{pH}$ sediaan terlalu tinggi akan mengakibatkan kulit menjadi kering saat penggunaan (Ainaro et al., 2015). Sediaan harus memenuhi persyaratan tersebut, karena apabila pH terlalu basa akan berakibat kulit menjadi bersisik, sebaliknya jika pH kulit terlalu asam dapat memicu terjadinya iritasi kulit (Swastika et al., 2013). Nilai $\mathrm{pH}$ yang diamati pada 12 hari menunjukkan rentang 5,0-7,0, $\mathrm{pH}$ yang didapat merupakan $\mathrm{pH}$ yang ideal untuk kulit. losion pelembab minyak tengkawang, losion baseline dan losion pelembab minyak biji durian dapat dilihat pada Gambar 1

\section{Perbandingan Nilai TEWL Minyak Biji Durian dan Minyak Tengkawang}

Pengukuran TEWL kulit yang diolesi losion minyak tengkawang, base losion, dan tanpa perlakuan dapat dilihat pada Gambar 2. Grafik tersebut menunjukkan bahwa pada 1 jam pertama minyak tengkawang mampu mengurangi penguapan air dari kulit hingga 35,23 \% terhadap kondisi awal. Pada jam kedua, ketiga, dan keempat minyak tengkawang mengurangi penguapan air dari kulit sebesar 31,33\%, $33,93 \%$ dan $27,9 \%$. Losion minyak tengkawang dapat mengurangi penurunan nilai TEWL kulit karena bersifat oklusif yaitu memperlambat lepasnya air dari kulit dengan membentuk lapisan hidrofob tipis pada permukaan kulit.

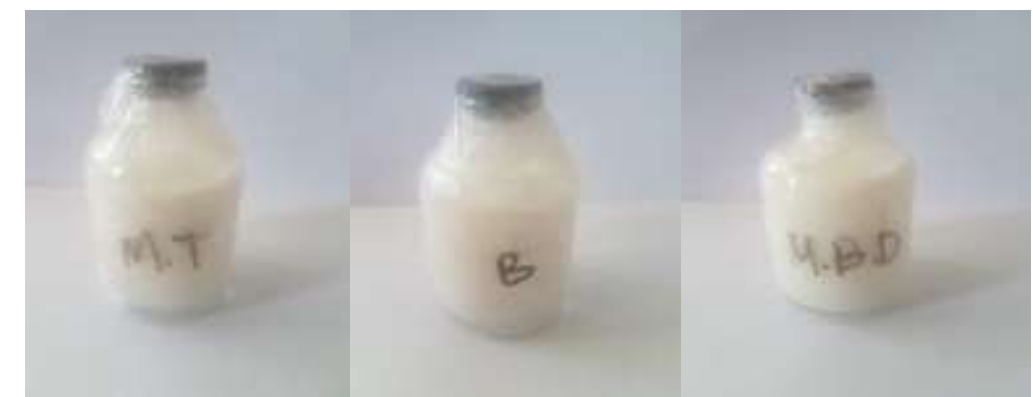

Gambar 1. Losion pelembab minyak tengkawang (MT), base losion (B) dan losion pelembab minyak biji durian (MBD) 
Lapisan hidrofob minyak ini menyebabkan air tertahan lebih lama di kulit. Kemampuan losion minyak tengkawang untuk mempertahankan nilai TEWL lebih baik dibandingkan dengan base losion dan tanpa perlakuan. Hal ini disebabkan karena asam oleat dan asam linoleat yang terkandung dalam minyak tengkawang merupakan unsur utama penyusun ceramid yang melekat pada lapisan stratum corneum. Asam lemak yang terdapat pada lapisan stratum corneum tersebut berperan untuk mempertahankan kandungan air dalam kulit. Oleh karena itu, dengan adanya losion minyak tengkawang dapat meningkatkan kemampuan ceramid untuk memperlambat pengauapan air kulit. Hal ini disebabkan karena asam oleat dan linoleat dari losion mebentuk lapisan selaput oklusif diatas permukaan kulit dan memperlambat penguapan kadar air kulit dibawah batas minimal yaitu $10 \%$ (Morino, 2001)

Tahap selanjutnya yaitu pengukuran TEWL kulit yang diolesi losion minyak biji durian. Pengukuran nilai TEWL kulit yang diolesi dengan losion minyak biji durian dilakukan dengan menimbang sebanyak 0,4 gram losion dan base losion sebagai pembanding. Sebelum diolesi dengan losion minyak biji durian dan base losion, dilakukan pengukuran nilai TEWL sebelum perlakuan untuk mengetahui baseline TEWL kulit. Setelah dilakukan pengukuran baseline TEWL, kemudian dioleskan losion minyak biji durian dan base losion pada tangan yang sudah ditandai dan dilakukan pengukuran nilai TEWL selama 4 jam. Hasil pengukuran nilai TEWL dari 15 sukarelawan dirata-ratakan tiap jamnya dan dibandingkan penurunan nilai TEWL dari losion minyak biji durian, base lotion dan tanpa perlakuan. Pengukuran nilai TEWL dari losion minyak biji durian disajikan dalam bentuk grafik pada Gambar 3.

Data nilai TEWL losion minyak tengkawang dan minyak biji durian tersebut menunjukkan terjadinya perbedaan antara nilai TEWL yang menggunakan losion minyak tengkawang dan losion minyak durian. Berdasarkan hasil analisis statistik $(\mathrm{p}<0,05)$ menunjukkan bahwa terdapat perbedaan bermakna antara penggunaan losion minyak tengkawang dan losion minyak biji durian. Oleh karena itu, maka dapat disimpulkan bahwa losion minyak tengkawang memberikan nilai TEWL lebih baik dibandingkan losion minyak biji durian dari pengujian selama 4 jam. Hal ini disebabkan karena dalam minyak tengkawang komposisi asam oleat lebih tinggi daripada minyak biji durian. Asam oleat berperan untuk mempermudah penyebaran minyak di permukaan kulit. Selain itu, dengan jumlah asam oleat yang tinggi pada minyak tengkawang akan membantu lapisan stratum corneum memperlambat proses penguapan air dari kulit dengan cara membentuk lapisan oklusif di atas permukaan kulit.

Berdasarkan hasil pengukuran nilai TEWL terhadap losion minyak tengkawang dan losion minyak biji durian dibandingkan dengan base losion sebagai 
kontrol positif dan tanpa perlakuan sebagai kontrol negatif maka dapat disimpulkan bahwa losion minyak tengkawang mampu mempertahankan kadar air pada kulit. Gambar 4. menunjukkan perbandingan pengukuran nilai TEWL kulit dengan menggunakan losion minyak tengkawang, losion minyak biji durian, base losion dan tanpa perlakuan.

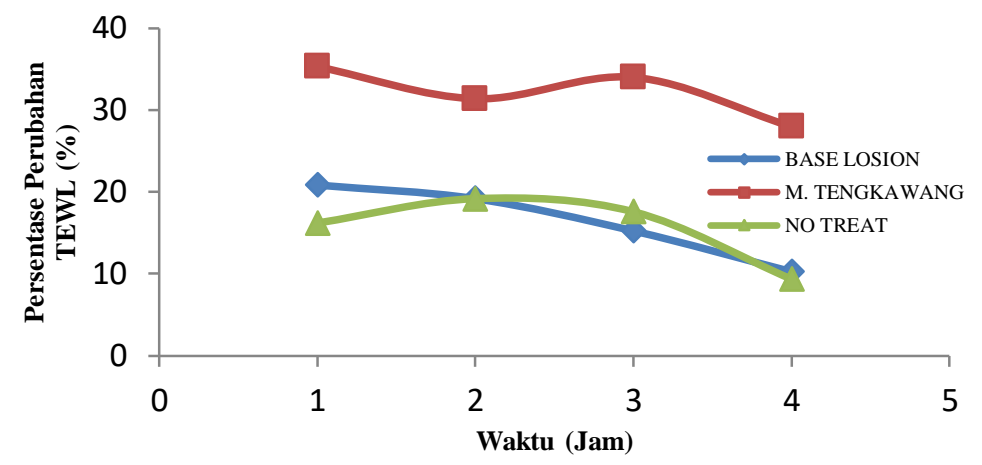

Gambar 2. Grafik Perbandingan Nilai TEWL Kulit yang Diolesi Losion Minyak Tengkawang, Base Losion dan Tanpa Perlakuan Terhadap Waktu

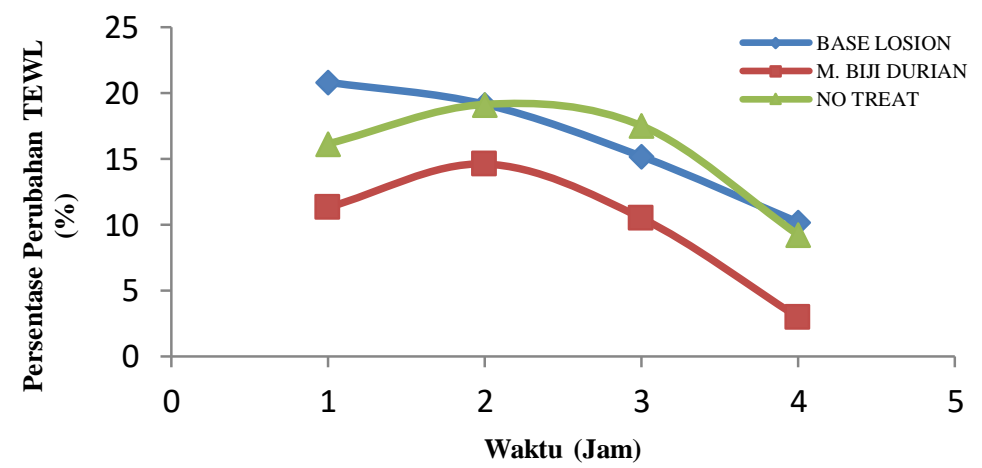

Gambar 3. Grafik Perbandingan Nilai TEWL Kulit yang Diolesi Losion Minyak Biji Durian dan Baseline Losion Terhadap Waktu

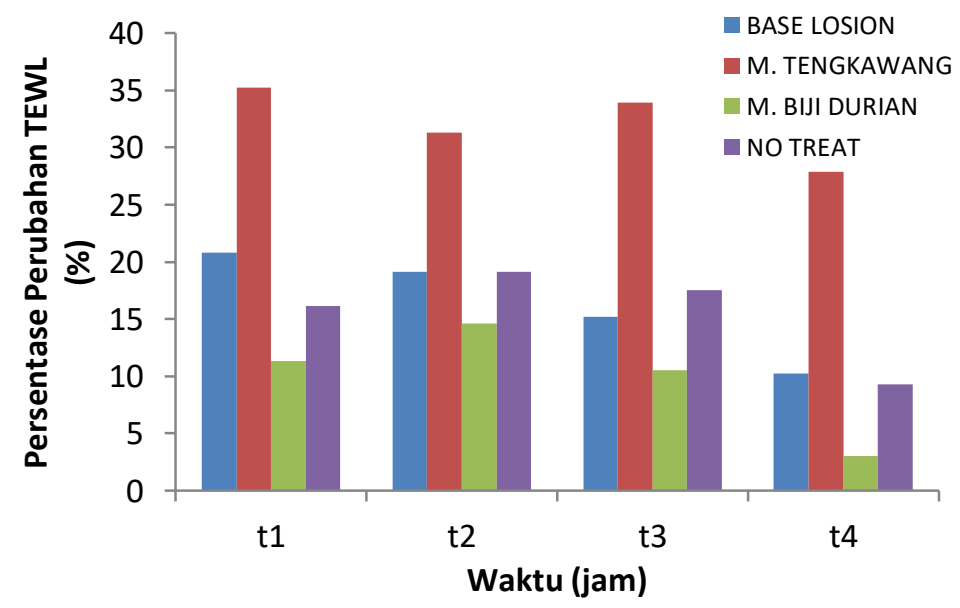

Gambar 4. Grafik perbandingan nilai TEWL losion minyak tengkawang, minyak biji durian, base losion dan tanpa perlakuan 


\section{SIMPULAN}

Uji iritasi ini termasuk dalam patch test atau tes sebelum bahan kosmetik dimasukkan dalam produk. Minyak tengkawang dan minyak biji durian yang digunakan dalam tes adalah minyak tengkawang dan minyak biji durian tanpa pengenceran (100\%). Minyak Tengkawang memberikan nilai TEWL lebih baik dibandingkan minyak biji durian dari pengujian selama 4 jam. Hal ini disebabkan karena dalam minyak tengkawang komposisi asam oleat lebih tinggi daripada minyak biji durian.

\section{UCAPAN TERIMA KASIH}

Terima kasih saya ucapkan kepada PT. Martina Berto atas kerjasama penelitian khususnya dalam penggunaan alat Tewameter dan pengujian TEWL. Terima kasih juga saya ucapkan kepada seluruh staff Martha Tilaar Inovation Centre yang telah banyak membantu dan memberi masukan pada penelitian ini.

\section{DAFTAR PUSTAKA}

Alander, J; Anncharlotte, A. And Christer, L. (2006), Cosmetic Emollients with High Stability Against Photo Oxidation, Lipid Technologi, 18: 226-230

Ainaro, E.P., Amilia, G., Sani, E.P. (2015). Formulasi Sediaan Masker Gel PellOff Mengandung Lender Bekicot (Achatina Fulica Bowdich) Sebagai Pelembab Kulit. Fakultas MIPA Unisba ISSN 2460-6472 Brown, M. J., (1997), Durio-A Bibliographic Review, IPGRI office for South Asia, New Delhi

Erungan, A.C., Sri, P., dan Syeni, B.D. (2009). Aplikasi Karaginan Dalam Pembuatan Skin Lotion. Bogor: Departemen Teknologi Dan Hasil Perairan Fakultas Perikanan Dan Ilmu Kelautan Institusi Pertanian Bogor

Gibbs S, Vietsch H, Meier U, Ponec M, Effect of skin barrier competence on SLS and water-induced IL-1a expression. Experimental Dermatology 2002: 11: $217-223$

Iswari, R \& Latifah, F. (2007). Buku pegangan ilmu pengetahuan kosmetik. Jakarta (ID): Jakarta, Gramedia Pustaka Utama.

Juwita, A. P., Yamlean P., Edy H. J. (2013) Formulasi Krim Ekstrak Etanol Daun Lamun (Syringodium isoetifolium). Skripsi, Universitas Sam Ratulangi

Kanengeiser, B., (2003), Evaluation of Skin Barrier Effects of Single Application of Topical Cosmetis Products via Transpidermal Water Loss Measurements, Clinical Research Laboratory Inc

Misnadiarly, A.S. (2006), Faktor-faktor yang Berpengaruh Terhadap Kesehatan Kulit, Cermin Dunia Kedokteran, 152:43-45

Morino, C. (2001), Skin Phydiology, Irritans, Dry Skin and Moisturizers, Washington State Departement of Labor and Industries, http://www.Ini.wa.gov/Safety /Reasearch/ Dermatitis/

Nesaretnam, K dan AR bin Mohd Ali. (1992). Engabkang (Illipe) - an Excellent Component for Cocoa Butter Equivalent Fat. Journal Science Food Agriculture. Vol. 60. Hal. 15-20. 
Sana. (2010). Pengaruh Ekstrak Minyak Biji Durian terhadap Transepidermal Water Loss (TEWL) Kulit. , Pontianak, Fakultas Matematika dan Ilmu Pengetahuan Alam, Universitas Tanjungpura, Skripsi.

Soerianegara and Lemmens, RHMJ (Editors). (1997), Plant Resourcees of South East Asia No. 5 (1). Timber Trees: Commercial Timbers. Bogor. Prosea,

Swastika, A. Mufrod \& Puwanto. (2013). Aktivitas Antioksidan Krim Ekstrak Tomat (Solanum lycopersicum L.), Trad Med Journal, 18(3), 132-140.

Tranggono, R.I.S dan Fatma, L., (2007), Buku Pegangan Ilmu Pengetahuan Kosmetik, Jakarta, Gramedia. 